\title{
PENYEMPROTAN DESINFEKTAN DI MUSHOLLA AN NUR, KELURAHAN SAWAH BARU, CIPUTAT, TANGERANG SELATAN
}

\author{
Munaya Fauziah ${ }^{1}$, Andriyani ${ }^{1}$, Ernyasih $^{1}$, Alien Mustika Ningsih ${ }^{2}$, Rohimi Zam Zam ${ }^{3}$ \\ ${ }^{1}$ Prodi Kesehatan Masyarakat, Fakultas Kesehatan Masyarakat, \\ Universitas Muhammadiyah Jakarta, Jakarta, Jl.K.H. Ahmad Dahlan, 15419 \\ ${ }^{2}$ Prodi Ilmu Hukum, Fakultas Hukum, \\ Universitas Muhammadiyah Jakarta, Jakarta, Jl.K.H. Ahmad Dahlan, 15419 \\ ${ }^{3}$ Fakultas Ilmu Pendidikan, \\ Universitas Muhammadiyah Jakarta, Jakarta, Jl.K.H. Ahmad Dahlan, 15419 \\ email: munaya.fauziah@umj.ac.id
}

\begin{abstract}
ABSTRAK
Kegiatan KKN online Kelompok 51 Universitas Muhammadiyah Jakarta Tahun 2020 mempunyai program kegiatan berupa penyemprotan desinfektan untuk mencegah penularan Covid-19. Kegiatan ini merupakan pengabdian kepada masyarakat yang dilakukan oleh dosen dan mahasiswa. Dengan diadakannya sosialisasi online ini diharapkan dapat memberikan kontribusi dalam masyarakat untuk mencegah penularan Covid-19 dan dapat menurunkan jumlah kasus Covid- 19. Hal ini diharapkan dapat memberikan manfaat secara kesehatan, sosial, ekonomi dan lingkungan. Sosialisasi ini diharapkan mampu memberikan wawasan dan pengetahuan sehingga dapat menerapkan disiplin dan hidup sehat di era new normal di masa pandemic covid-19.
\end{abstract}

Kata kunci: covid-19, KKN online, penyemprotan desinfektan

\begin{abstract}
The group 51 Muhammadiyah University of Jakarta online KKN activities in 2020 have an activity program in the form of spraying desinfectants to prevent Covid-19 transmission. This activity is a community service carried out by lecturers and students. By holding this online socialization, it is hoped that it can contribute to society to prevent the transmission of Covid-19 and be able to reduce the number of Covid-19 cases. This is expected to provide health, social, economic and environmental benefits. With this socialization, it is expected to be able to provide insight and knowledge so that they can apply discipline and live a healthy life in the new normal era during the Covid-19 pandemic.
\end{abstract}

Keywords: covid-19, KKN online, desinfectan spraying 


\section{PENDAHULUAN}

Sejak Covid-19 pertama kali dilaporkan oleh WHO di Wuhan China pada akhir Desember 2019, saat ini telah menyebar ke lebih dari 180 negara termasuk Indonesia. Semua negara berupaya mempersempit penyebaran virus Covid-19 yang ditransmisikan antar manusia melalui droplet (WHO, 2020). Virus corona ini diyakini pertama kali muncul di pasar grosir di pusat kota Wuhan, China (Kompas, 2020). Sejak saat itu virus corona mulai merambah ke setiap kota di China sampai ke negara tetangga, dan sekarang sudah masuk di Indonesia bahkan dunia sudah dikuasai oleh virus yang mematikan ini, yang belum kita ketahui obatnya.

Menurut situs online Republika, terdapat panduan Covid-19 dan 14 aturan cegah virus corona, yaitu :

a) Panduan Covid-19:

1. Gejala :

Gejala yang paling umum adalah demam, kelelahan dan batuk kering. Pada beberapa pasien, mungkin ada rasa sakit dan nyeri, hidung tersumbat, pilek, sakit tenggorokan atau diare.

2. Virus Covid-19 ditularkan melalui tetesan cairan pernapasan, bukan udara. dan antibiotik tidak efektif karena Covid-19 disebabkan oleh virus dan antibiotik tidak ampuh melawan virus.

3. Sampai saat ini, tidak ada vaksin atau obat antivirus khusus untuk mencegah atau mengobati Covid-19. Studi tentang pengembangan obat dan vaksin sedang dilakukan dan sejumlah vaksin dan beberapa obat tertentu sedang diuji.

4. Harus menggunakan masker ketika keluar dari rumah, dan pemakaian masker hanya dipakai 1 kali saja.

5. Virus dapat hidup di permukaan selama beberapa jam atau hingga beberapa hari. Waktunya dapat bervariasi tergantung pada jenis permukaan, suhu lingkungan atau kelembaban.

b) 14 aturan cegah virus corona :

1. Sering-seringlah mencuci tangan dengan sabun dan air selama 20 detik.

2. Tutup mulut dan hidung Anda dengan tisu sekali pakai selama batuk dan bersin. Jika tidak ada lap, gunakan bagian dalam siku.

Agar masyarakat lebih sadar akan pentingnya penerapan protokol kesehatan ketika keluar dari rumah, pemerintah selalu memberikan arahan dan upaya pencegahan penyebaran Covid-19 di masa pandemi seperti saat ini. Namun, tidak hanya pemerintah saja yang memberikan arahan tersebut, tetapi seluruh masyarakat termasuk mahasiswa pun ikut andil dalam memberikan arahan penerapan protokol kesehatan untuk menghadapi masa pandemi saat ini. Seperti mahasiswa UMJ dalam program Kuliah Kerja Nyata (KKN), memanfaatkan waktu tersebut untuk memberikan arahan protokol kesehatan kepada masyarakat. Program tersebut bisa dilakukan dengan cara terjun langsung ke lingkungan masyarakat.

Banyak masyarakat yang keluar rumah dan beribadah ditempat-tempat ibadah umum, seperti masjid atau musholla. Musholla An Nur berada di Kelurahan Sawah Baru, Ciputat, Tangerang Selatan, Provinsi Banten. Suasana peribadahan di musholla ini tetap dilaksanakan meskipun terjadi pandemi oleh karena itu diperlukan kegiatan yang dapat memutus rantai penularan dalam ruangan salah satunya yaitu penyemprotan desinfektan.

Virus corona merupakan penyebab Covid-19. Virus sangat berbeda dengan bakteri dalam hal ukuran yaitu 40-160 nm, memiliki struktur berupa tonjolan glikoprotein dan 
membran protein berbentuk amplop yang memiliki kemiripan struktur dengan virus SARSCoV hingga 75-90\%. Struktur gen pada Covid-19 juga mirip dengan SARS-CoV (>80\%). Covid-19 akan inaktif jika terkena sinar ultraviolet dan suhu tinggi serta disinfektan yang bersifat lipofil (larut lemak) yaitu, eter, etanol, klorin, asam peroksi asetat dan kloroform (WHO, 2020). Virus penyebab Covid-19 akan berkembang biak dalam tubuh manusia dalam masa inkubasi 3-7 hari bahkan hingga 14 hari. Sepanjang daya tahan tubuh manusia yang terinfeksi cukup, maka virus penyebab Covid-19 akan mati dengan sendirinya (self limiting disease). Hingga saat ini belum ada obat antivirus yang spesifik direkomendasikan untuk terapi Covid-19, sehingga upaya yang dapat dilakukan adalah upaya pencegahan penyebaran (transmisi) virus dengan mencuci tangan dengan sabun atau hand sanitizer lebih sering dengan air mengalir, menghindari menyentuh area muka, jika batuk dan bersin ditutupi dengan lengan atas atau sapu tangan, hindari kerumunan dan menerapkan pola hidup bersih dan sehat (PHBS)/ gerakan masyarakat hidup sehat (GERMAS). Makan dengan gizi seimbang adalah makanan empat sehat lima sempurna dengan porsi sayur dan buah 2-5 porsi dalam sehari merupakan upaya untuk mempertahankan daya tahan tubuh melawan infeksi Covid-19.

Salah satu cara memutus rantai penularan Covid-19 adalah dengan menjaga kebersihan dengan membunuh virus Covid-19 sebelum ia menginfeksi manusia. Berbagai cara diantaranya adalah menggunakan antiseptik untuk membasuh tangan dan bagian tubuh dan disinfektan yang disemprotkan atau diusapkan pada berbagai benda mati yang mungkin terpapar virus. Namun demikian saat ini muncul fenomena penyemprotan disinfektan secara massif pada berbagai tempat, bahkan langsung kepada manusia dengan alasan untuk membunuh virus yang mungkin menempel pada baju atau badan manusia. Sebelum kita membahas hal tersebut, mari kita kenali dulu istilah-istilah antiseptik dan disinfektan.

\section{MASALAH}

Masyarakat belum memahami bahwa salah satu penularan Covid-19 melalui udara di dalam ruangan yang tertutup. Oleh sebab itu, kelompok KKN online UMJ kelompok 51 mengadakan sosialisasi pencegahan penularan Covid-19 kepada masyarakat salah satunya dengan penyemprotan desinfektan.

\section{RENCANA PEMECAHAN MASALAH}

Masyarakat masih bersosialisasi diluar rumah termasuk beribadah di tempat peribadatan umum seperti masjid atau musholla tanpa mengkhawatirkan adanya Covid-19 disekitar mereka. Penyemprotan desinfektan di tempat ibadah ini dilaksanakan sebagai bentuk andil mahasiswa untuk memberikan praktek langsung untuk meningkatkan pemahaman dan kecakapan dalam pencegahan penularan Covid-19 di masa pandemi seperti saat ini.

\section{METODE}

Kelompok memilih lokasi tempat ibadah umum yang sesuai dengan sumber daya yang dimiliki oleh kelompok. Sumber daya yang dimiliki berdasarkan kriteria input meliputi man, money, material, methode, dan machine. Lokasi tempat ibadah umum yang terpilih yaitu Musholla An Nur RT.05 RW.02 Villa Mutiara Kelurahan Sawah Baru, Kecamatan Ciputat, Kota Tangerang Selatan. Selanjutnya dilakukan proses kegiatan di lapangan berupa perizinan kepada pengurus tempat ibadah terpilih. Kelompok menyiapkan alat dan bahan yang diperlukan untuk penyemprotan desinfektan pada hari yang ditentukan. Pelaksanaan penyemprotan desinfektan mengikutsertakan pengurus Musholla dan perwakilan masyarakat sekitar. 
AS-SYIFA: Jurnal Pengabdian dan Pemberdayaan Kesehatan Masyarakat

\section{HASIL DAN PEMBAHASAN}

Penyemprotan desinfektan di Musholla An Nur dilaksanakan pada tanggal 21 Juli 2020. Pengurus musholla dan masyarakat sekitar sangat mendukung dan berterima kasih atas pelaksanaan kegiatan penyemprotan desinfektan di area tempat ibadah mereka. Dari pelaksanaan penyemprotan desinfektan ini, pengurus Musholla An Nur dan masyarakat sekitar pengguna musholla merasa adanya peningkatan pemahaman dan keamanan terhadap penularan Covid-19. Pelaksanaan kegiatan secara keseluruhan berjalan lancar tanpa hambatan berarti. Berikut Dokumentasi sosialisasi yang dilakukan.

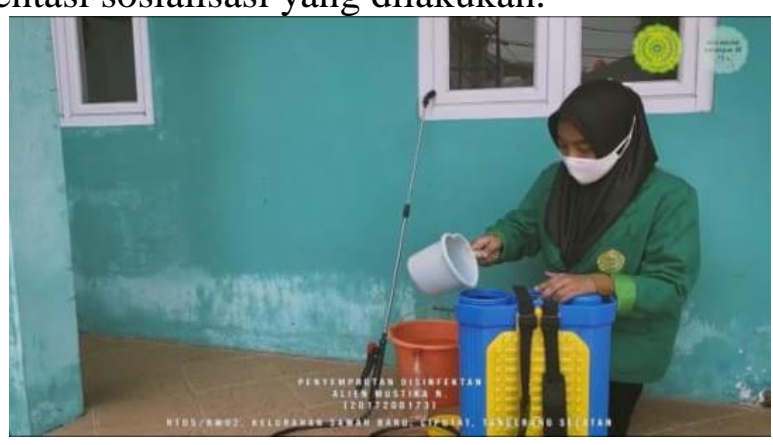

Gambar 1. Mengisi tabung semprot dengan cairan desinfektan

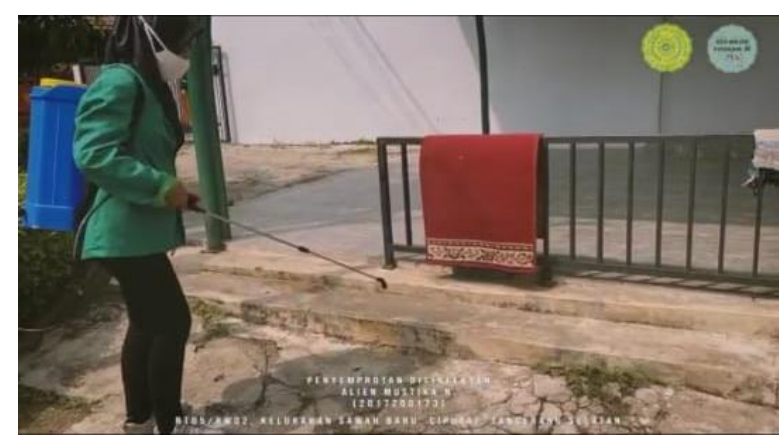

Gambar 2. Penyemprotan di serambi musholla

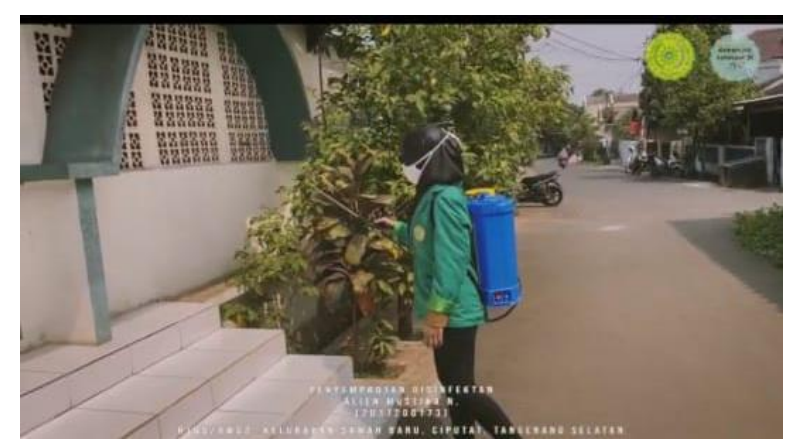

Gambar 3. Penyemprotan di tangga masuk musholla

Penyemprotan di ruang publik dilakukan oleh banyak lembaga (BNN, 2020; Dinkes Pemkab. Buleleng, 2020). Namun perlu diperhatikan dampak kesehatan yang terjadi bila penyemprotan desinfektan dilakukan secara terus menerus. Penularan covid terjadi terutama karena adanya kontak dari satu penderita ke orang yang sehat disekitarnya. Oleh karena itu pencegahan melalui pembatasan kontak, menggunakan masker, menjaga jarak, menjaga kebersihan perorangan dan kebersihan lingkungan lebih diutamakan (Media Indonesia, 2020). 
Volume. 1 No. 2 tahun 2020 Nov 2020 - Mei 2021
ISSN (online): 2722-2055 https://jurnal.umj.ac.id/index.php/AS-
AS-SYIFA: Jurnal Pengabdian dan Pemberdayaan Kesehatan Masyarakat

\section{KESIMPULAN DAN SARAN}

Kegiatan penyemprotan desinfektan yang dilaksanakan di Musholla An Nur Kelurahan Sawah Besar Ciputat Tangerang Selatan merupakan kegiatan pengabdian masyarakat yang dimaksudkan untuk memutus rantai penularan pandemi yang terjadi sekitar wilayah tersebut khususnya maupun di Tangerang Selatan umumnya. Semoga kegiatan tersebut dapat memberikan manfaat kepada pengurus, jemaah musholla dan masyarakat sekitar.

\section{UCAPAN TERIMA KASIH}

Kami mengucapkan terimakasih kepada LPPM Universitas Muhammadiyah Jakarta yang telah mendanai dan memfasilitasi KKN UMJ Online 2020

\section{DAFTAR PUSTAKA}

Selidiki Asal-Usul Covid-19, WHO Kirim Tim Ahli Ke China Retrieved Oktober 5, 2020, from Kompas.website:

https://www.kompas.com/global/read/2020/07/11/070000770/selidiki-asal-usul-covid-19who-kirim-tim-ahli-ke-china?page=all

Panduan Covid-19 dan 14 Aturan Cegah Virus Corona Retrieved Oktober 5, 2020, from Republika.website: $\quad$ https://republika.co.id/berita/qa383v440/panduan-covid19-dan-14aturan-cegah-virus-corona

WHO.2020. Modes of transmission of virus causing COVID-19: implications for IPC precaution recommendations. Diakses dari: https://www.who.int/newsroom/commentaries/detail/modes-of-transmission-of-virus-causing-covid-19-implicationsfor-ipc-precaution-recommendations

BNN. 2020. Cegah Corona BNN Semprotkan Cairan Desinfektan. Diakses dari https://bnn.go.id/cegah-penyebaran-virus-corona-bnn-ri-semprotkan-cairan/

Dinkes Pemkab Buleleng. 2020. Pencegahan Dini Corona, Pemkab Buleleng Laksanakan Penyemprotan Desinfektan Serentak. Diakses dari https://dinkes.bulelengkab.go.id/berita/pencegahan-dini-corona-pemkab-bulelenglaksanakan-penyemprotan-desinfektan-serentak-92

Media Indonesia. 2020. Efektifkah Penyemprotan Disinfektan untuk Atasi Covid-19? Diakses dari: https://mediaindonesia.com/read/detail/298663-efektifkah-penyemprotan-disinfektanuntuk-atasi-covid-19 
